\title{
Exploring the Potential and Limitations of PCR-RFLP and PCR-SSCP for SNP Detection: A Review
}

\author{
Hayder O. Hashim ${ }^{1}$, Mohammed Baqur S. Al-Shuhaib ${ }^{2 *}$ \\ 'Department of Clinical Laboratory Sciences, College of Pharmacy, University of Babylon, Babil 51001, Iraq \\ ${ }^{2}$ Department of Animal Production, College of Agriculture, Al-Qasim Green University, Al-Qasim 8, Babil 51001, Iraq
}

Corresponding Author: Mohammed Baqur S. Al-Shuhaib, PhD, Assistant Professor, Department of Animal Production, College of Agriculture, Al-Qasim Green University, Al-Qasim 8, Babil 51001, Iraq. Tel: +964-7707115693, Email: mohammed79@agre. uoqasim.edu.iq; baquralhilly_79@yahoo.com

Received July 29, 2019; Accepted November 13, 2019; Online Published December 5, 2019

\begin{abstract}
Polymerase chain reaction-single-strand conformation polymorphism (PCR-SSCP) and PCR-restriction fragment length polymorphism (PCR-RFLP) are two independent methods used in the post-amplification genotyping of DNA variations. Both techniques are used in a wide range of screening applications to characterize single nucleotide polymorphisms (SNPs). The PCR-SSCP enables the identification of a potentially causative unknown SNP that could not be identified by PCR-RFLP. However, because complicated steps are not required to perform PCR-RFLP, it is used in many applications. On the other hand, PCR-RFLP is easier to process in terms of time and handover experience, the detection of a particular unknown SNP by PCR-SSCP has further chances. The simplicity of PCR-RFLP does not mean that it is better than PCR-SSCP. The reason is the limited ability of PCR-RFLP to detect nucleotide variations, which often go undetected because each restriction enzyme (RE) scans only a few recognition sequences, and other sequences are ignored. Furthermore, the efficacy of PCR-SSCP is sometimes hindered by many optimizations and also lack of experience. As PCR-SSCP allows other sequences within an amplicon to be separated and characterized, the choice between PCR-RFLP and PCR-SSCP is largely dependent on the reason for each genotyping experiment. This review provides a useful guide for comparing PCR-RFLP and PCR-SSCP in terms of their concepts, efficiency, ease of use, interpretation, and sensitivity as well as several other parameters. The comparison is extended to the practical applications of both techniques in terms of their utilization in molecular diagnostics and related applications.

Keywords: Genotyping, Mutation, Polymorphism, Post-PCR Screening, Protocols

Citation: Hashim HO, Al-Shuhaib MBS. Exploring the potential and limitations of PCR-RFLP and PCR-SSCP for SNP detection: a review. J Appl Biotechnol Rep. 2019;6(4):137-144. doi:10.29252/JABR.06.04.02.
\end{abstract}

\section{Introduction}

The gold-standard method for the identification of mutations in polymerase chain reaction (PCR) amplicons is direct sequencing. Unfortunately, sequencing the reactions of all PCR amplicons is expensive, laborious, and time-consuming, particularly in large-scale applications. ${ }^{1}$ Nucleic acid-based techniques are mainly used to access and explore phenotype variations between analyzed individuals. In this process, genomic DNA is extracted, a particular genetic locus is targeted, and PCR is performed. Hence, several post-PCR genotyping techniques are available to identify the variations in nucleic acid sequences, such as denaturing gradient gel electrophoresis (DGGE), temperature gradient gel electrophoresis (TGGE), chemical mismatch cleavage (CMC) method, and amplification refractory mutation system (ARMS), which are applied to visualize the nucleic acid variations in a range of efficiencies and sensitivity. Similarly, the requirements for creating a gradient gel have reduced the availability of both DGGE and TGGE. Furthermore, the necessity of using high-cost fluorescence-labeled probes in $\mathrm{CMC}$ has reduced its popularity, ${ }^{2}$ and both time and cost may be increased when PCR-ARMS is applied. ${ }^{3}$ For these reasons, the widespread adoption of these post-PCR genotyping techniques has been restricted to use in a limited number of applications. In contrast with the above- mentioned techniques, PCR-RFLP and PCR-SSCP have been widely used to genotype amplified products, which has increasingly been reported in the literature. ${ }^{4-6}$ Despite the development of high-throughput next-generation sequencing and whole exon sequencing, ${ }^{7}$ the accumulated data on both techniques have been continuously reported. ${ }^{8,9}$ It is worth mentioning that in addition to being valuable for the determination of intraspecies variation, ${ }^{10}$ both techniques have been employed in species identification and differentiation. Furthermore, both techniques have been used to differentiate many organisms to species level by the amplification of a conserved region of the mitochondrial D-loop, ${ }^{11,12}$ ribosomal regions, ${ }^{13,14}$ or other genetic loci. ${ }^{15,16}$ However, although PCR-SSCP can be applied to any gene in any organism, PCR-RFLP has less spectrum superiority. Nevertheless, PCR-RFLP has attracted researchers' attention worldwide because of its low costs and does not require advanced instruments. ${ }^{17}$ Despite the wide

Copyright $\odot 2019$ The Author(s). This is an open-access article distributed under the terms of the Creative Commons Attribution License (http:// creativecommons.org/licenses/by/4.0), which permits unrestricted use, distribution, and reproduction in any medium, provided the original work is properly cited. 
versatility of both techniques, no comprehensive review has been reported to have compared PCR-SSCP and PCR-RFLP in terms of sensitivity, efficiency, technical requirements, time, costs, and other related aspects. For this reason, little is known about when and how to select one of these techniques to address genotyping issues. Many researchers need guidelines for selecting between PCR-RFLP and PCR-SSCP in terms of their intended applications. Accordingly, in the present study, a direct comparison has been made between both techniques to enlighten researchers who plan to genotype PCR amplicons by helping them decide which one should be utilized in a specific application. Therefore, the objective of this review is to provide a technical comparison between PCR-RFLP and PCR-SSCP and to determine which one is the most suitable for post-PCR screening.

\section{The Concepts of the Techniques}

The PCR-RFLP, which is also known as cleaved amplified polymorphic sequence, was invented by Botstein et al. ${ }^{18}$ In this technique, a PCR amplicon is treated by a certain RE that cuts the DNA in a unique restriction site, which is known as the recognition site, to generate several DNA fragments in various sizes. Subsequently, the digested amplicons are loaded onto a gel, and an electric field is applied. The differently sized bands will move at varying distances across the gel. ${ }^{19}$ The PCR-SSCP technique was originally applied by Orita et $\mathrm{al}^{20}$ to identify possible point mutations within PCR amplicons. The main concept of PCR-SSCP is based on the initial separation (melting) of the double-stranded forms by heat into singlestranded forms. In the separated state, the molecules tend to fold into a three-dimensional conformation according to their nucleic acid sequences. Thus, in the polyacrylamide gel electrophoresis, the separated single strands of DNA molecules occupy the same size but accommodate different three-dimensional structures with different mobilities. Such structural conformations are affected by a mutation at a particular nucleotide position in the primary sequence, which can alter the physical conformation of the denatured singlestrand bands. This alteration often leads to the slightly tilted positioning of the mutant single-strand bands with respect to their normal counterparts in the neutral polyacrylamide gels. $^{21}$

\section{Simplicity of Use}

The most powerful aspect of PCR-RFLP is its simplicity. The PCR-RFLP can be performed without the need for considerable experience in molecular biology. However, despite the ease of use and extreme simplicity of PCR-RFLP, it is confined only with the recognition site of RE (Figure 1), and other sequences are ignored unless double digestion is used with another RE. Thus, the main limitations of PCRRFLP are the requirement for specific RE and the difficulty of identifying the exact variation in the event in which several SNPs are being targeted at the same time. However, the mixing of two enzymes in one reaction mixture can partially solve this problem. ${ }^{22}$ Nevertheless, regarding digestion, there are further complications because of the different types of cofactors and the concentrations needed for each RE to undertake its scheduled task of standardized digestion. ${ }^{17}$ In addition, the higher costs of PCR-RFLP resulting from the higher costs of double or triple digestion have added another inevitable limitation that could not be excluded from postPCR screening experiments.

With regard to PCR-SSCP, several previous reports indicated the simplicity of this technique. ${ }^{23-25}$ Compared with PCR-RFLP, there is considerable difficulty in PCR-SSCP. Although the electrophoresis of PCR amplicons is carried out in neutral conditions, they should be prepared before being loaded onto polyacrylamide gels, including denaturation with an appropriate SSCP loading dye for 5-10 minutes and chilling in ice for at least 10 minutes. Another difficulty in PCR-SSCP is that it cannot be used to predict the exact conformation

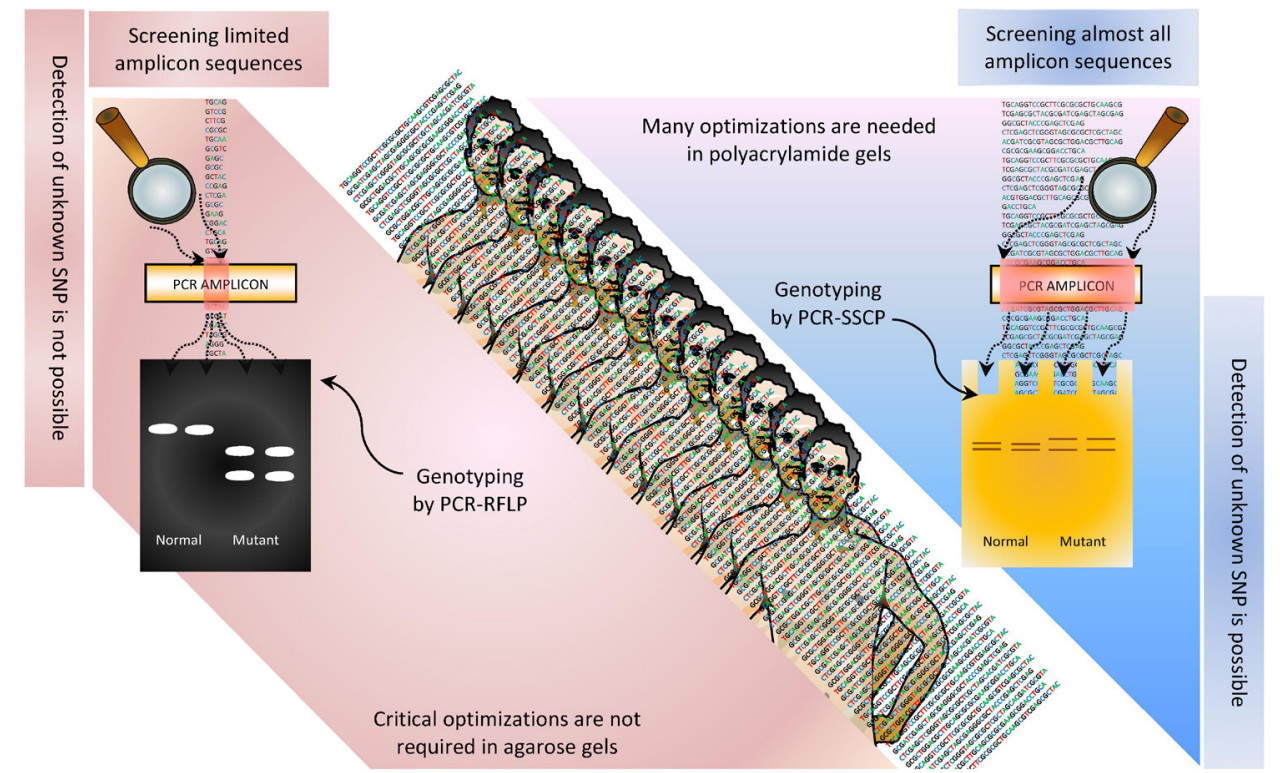

Figure 1. Limitations and Advantages of PCR-RFLP (Left) and PCR-SSCP (Right) Techniques in Terms of the Ability of Each Particular Technique to Identify the Unknown SNP(s). The red color surrounding the PCR amplicon refers to the limits of polymorphisms detection in each technique. 
of a DNA fragment under different parameters. ${ }^{26}$ Therefore, optimizing the conditions of PCR-SSCP electrophoresis for each specified type of PCR product is necessary to control the porosity of the gels, amplicons sizes, loaded amplicons, the voltage applied, and other variable parameters. ${ }^{27}$ Therefore, several optimization steps should be conducted to circumvent the undesired low resolutions that might occur in PCR-SSCP. The optimization of PCR-SSCP is achieved in a series of experiments that should be performed to increase the resolution of PCR-SSCP, such as polyacrylamide gel concentration $(8 \%-14 \%)$, temperature $\left(4-20^{\circ} \mathrm{C}\right)$, and voltage $(5-10 \mathrm{~V} / \mathrm{cm})$. Other optimizations are required in common PCR-SSCP experiments, including the choice of gel dimension format and the possibility of glycerol being mixed with the neutral gel. ${ }^{28}$ Moreover, it is sometimes necessary to perform pre-electrophoresis before loading PCR amplicons onto gels. Although several parameters of PCR-SSCP could be arranged, some optimizations may increase the difficulty of these experiments. However, in some PCR experiments, it is not necessary to conduct all the optimizations in all amplicons, as many of them may yield reasonable SSCP bands by relying on only one procedure. Therefore, such procedures are mandatory when no differences are observed among the analyzed PCR products.

\section{Staining Requirements}

With regard to staining amplicons in PCR-RFLP, any commercially available dye is sufficient to stain the digested amplicons. This step can be further simplified by adding the staining dye to the agarose gel before it is polymerized. ${ }^{29}$ However, this simplification could slightly halt the movement of the digested DNA molecules. However, in all cases, the dyes used in agarose gel, including the commonly used ethidium bromide, are less sensitive than silver nitrate by about 100fold. Similarly, the agarose gel that is commonly used in PCR-RFLP does not have a high sieving ability compared to the polyacrylamide gel, which is usually used in PCR-SSCP experiments.

In contrast to simple staining methods described in PCRRFLP, PCR-SSCP is associated with complicated silver-staining procedures. ${ }^{30}$ Because of the sensitivity of silver staining reagents, stringent precautions should be taken into account to obtain the best results. These precautions are not only taken in the preparation of the staining kit but also extended to the procedures used to develop the bands. ${ }^{31}$ There are two types of bands in polyacrylamide gels: double-stranded, nondenatured bands (dsDNA), and single-stranded, denatured bands (ssDNA). The ssDNA is the highest concern of all optimizations, as it is the region at which a researcher expects to see a possible variation between the normal and mutant ssDNA bands. When such slight differences are observed between the wild type and the altered DNA in the ssDNA region, the task of PCR-SSCP is completed.

\section{Time Requirement}

The time required to process the samples is divided into two stages: in vitro digestion of amplicons with $\mathrm{RE}$ and electrophoresis. In digestion with REs, the variable times of incubation are required, which vary according to the type of used RE. However, for some enzymes, such as HinfI, the incubation time is $30 \mathrm{~min}$, whereas the standard incubation time is 60 minutes, which is required by almost all enzymes to digest their target recognition sequences. Nevertheless, the incubation time may be extended overnight (or about 17 hours). Because of the extended period of incubation with endonucleases, PCR-RFLP could be considered, in these cases, as a time-consuming method. ${ }^{32}$ It is noteworthy that although the brand of RE is a key factor, it is sometimes not considered. However, the quality of synthesized enzymes in terms of the type and the proficiency of the recombinant DNA technology used to generate such enzymes may vary from manufacturer to manufacturer. Therefore, the same RE produced by two manufacturers may differ in cost, expiry date, transportation conditions, efficiency of digestion, time needed for incubation, and other parameters. In addition, in some experiments, incubation times are extended to ensure efficient digestion. Nevertheless, there is no guarantee that acceptable results will be achieved in all cases because some REs tend to lose efficiency after being incubated with amplicons for extended periods. ${ }^{33}$ Moreover, any change in the RE and the buffer concentration may lead to undesirable outcomes. ${ }^{34}$ Therefore, optimization is needed for both the incubation time and the brand of RE used in the incubation. ${ }^{35}$ Regardless of the time required for incubation, the time needed to run the digested amplicons is only $20-30$ minutes at $7 \mathrm{~V} / \mathrm{cm}$, which usually yields the intended results. In previous protocols, different periods were used to perform electrophoresis in PCR-SSCP, which differed in terms of the duration required to obtain adequate separation among the genotyped samples. Some protocols relied on only 4 hours of electrophoresis with applying high constant voltage, ${ }^{36}$ while in other procedures, extended periods up to 20 hours were used to run amplicons. In these periods, a lower voltage was applied, and constant temperature control was achieved by recirculating chillers. ${ }^{37}$ However, several optimizations are highly recommended before the application of each procedure.

\section{Recommended Sizes of Amplicons}

The size of the amplicons in PCR-RFLP does not limit the successful performance of its use. The reason is that PCRRFLP does not rely on the physical status of the amplicon. Instead, the presence or absence of a recognition sequence is the only rate-limiting step; otherwise, the intended RE does not pay attention to the length of its corresponding amplicon. The PCR-RFLP is usually conducted on horizontal agarose gels. However, to conduct a successful PCR-RFLP, a high concentration of amplicons is needed ${ }^{38}$ because of the limited capability of agarose gels to separate molecules compared with the highly sensitive polyacrylamide gels. It is worth mentioning that PCR-RFLP can be conducted on a vertical polyacrylamide gel, and the amplicons can be detected by highly sensitive silver-staining kits. ${ }^{39}$ However, this protocol is not usually applied in PCR-RFLP because almost all procedures take place in horizontal agarose formats. The PCR-SSCP can detect polymorphism up to 500 bp fragments, which, however, are optimized between a capacity of 200-600 
bp. To accommodate as many nucleic acids as possible without being affected by the low efficiency of PCR-SSCP detection, the optimal size of amplicons should range between 330 and $380 \mathrm{bp}$. However, PCR-SSCP requires only a small number of amplicons to undergo optimal electrophoretic separation on polyacrylamide gels. This feature is derived from the ability of the post-electrophoresis silver-staining technique to detect extremely low concentrations of DNA. Thus, PCR-SSCP is usually performed by applying amplicons that are $2 \mu \mathrm{L}$, which saves residual amounts for other applications. Moreover, loading small sizes of amplicons enhances the staining sensitivity of silver nitrate.

\section{The Choice Between PCR-RFLP and PCR-SSCP}

The PCR-SSCP is sometimes difficult to understand because of the multitude of interacting factors and outcomes of each genotype amplicon. However, the interpretation of PCR-RFLP results is easy compared to PCR-SSCP because of previously designed amplicons, recognition sequences, and the expected sizes of the digested fragments. However, this does not mean that the superiority of PCR-RFLP over PCR-SSCP as PCRSSCP has significant advantages over PCR-RFLP in providing the accurate detection of nucleic acid variations. ${ }^{21}$ Therefore, the choice of the most appropriate method could depend on the targeted purpose of genotyping. If only one SNP is being genotyped in a certain population, the choice will usually be PCR-RFLP. In contrast, PCR-SSCP is favored when the largescale screening of all amplicons is required in searching for previously unknown data (Table 1).

\section{Applications}

Both the PCR-RFLP and PCR-SSCP techniques have been recently in several species, ranging from humans to microorganisms. The apparent superiority of PCR-RFLP was observed regarding its broad utilization in several aspects of medical human genetics, such as the diagnosis of carcinogenesis, parasitic infection, gastritis, urinary tract infection, arthrosclerosis, infertility, and blood grouping. ${ }^{40-48}$ This higher reliability on PCR-RFLP may be attributed to its simplicity compared with PCR-SSCP, because of which it has been used in previous SNP-specified applications. In contrast to medical applications, PCR-RFLP has not exhibited superiority compared with PCR-SSCP. This alteration has been well documented in several domestic animals in which many genotype-phenotype studies were performed. Several productive and reproductive traits that depend on SNPs were detected by PCR-SSCP, such as wool characteristics, milk synthesis, carcass weight, meat tenderness, and biochemical parameters $^{49-54}$ (Table 2). However, PCR-RFLP applications were used in the detection of pork contamination in frozen meat products. ${ }^{55}$ The same results observed in domestic animals using PCR-RFLP were obtained in assessing the possible adulteration of sausage products made with chicken. ${ }^{56}$ Moreover, PCR-RFLP has also been considered in the study of some growth and performance traits. ${ }^{57}$ However, PCRSSCP was considered as a cornerstone in recent post-PCR genotyping studies on poultry, such as egg-production traits, body weight characteristics, and intramuscular fat content. ${ }^{58-60}$ Because of its powerful ability to identify unknown $\mathrm{SNP}(\mathrm{s})$,

Table 1. The Main Differences Between PCR-RFLP and PCR-SSCP Methods

\begin{tabular}{|c|c|c|}
\hline Parameter of Comparison & PCR-RFLP & PCR-SSCP \\
\hline - Based on the presence or absence of the recognition sequences & $\checkmark$ & $x$ \\
\hline - Based on physical and chemical differences between the normal and mutants single-strand DNA & $x$ & $\checkmark$ \\
\hline - Detection of unknown mutation(s) is possible & $x$ & $\checkmark$ \\
\hline - It's costly in large-scale applications & $\checkmark$ & $x$ \\
\hline - Digestion with restriction enzymes is required & $\checkmark$ & $x$ \\
\hline - It's always necessary to perform sequencing reactions & $x$ & $\checkmark$ \\
\hline - A considerable technical experience is required & $x$ & $\checkmark$ \\
\hline - Electrophoresis is usually performed on horizontal agarose-based gel format & $\checkmark$ & $x$ \\
\hline - Electrophoresis is usually performed on a vertical polyacrylamide-based gel format & $x$ & $\checkmark$ \\
\hline - Special optimizations, such as temperature, gel concentration, voltage, are required & $x$ & $\checkmark$ \\
\hline - Staining is usually simple and can be completed by only one step & $\checkmark$ & $x$ \\
\hline - Short time is sufficient for processing samples before conducting electrophoresis & $x$ & $\checkmark$ \\
\hline - Only a short time is needed for electrophoresis & $\checkmark$ & $x$ \\
\hline - Controlling temperature is required in electrophoresis & $x$ & $\checkmark$ \\
\hline - It is the favoured technique in working on a previously known SNP & $\checkmark$ & $x$ \\
\hline - Larger gel format is sometimes needed & $x$ & $\checkmark$ \\
\hline - Sizes of amplicons are essential in genotyping efficiency & $x$ & $\checkmark$ \\
\hline - Very low sample concentration is required for electrophoresis & $x$ & $\checkmark$ \\
\hline - Stained bands are easy to be read and interpret in almost all cases & $\checkmark$ & $x$ \\
\hline - Few specific nucleotides are targeted, while other sequences are ignored & $\checkmark$ & $x$ \\
\hline - It's suitable to simultaneously analyze many SNPs in the same amplicon & $x$ & $\checkmark$ \\
\hline - The exact conformation of genotyped bands could be predicted in electrophoresis & $x$ & $\checkmark$ \\
\hline
\end{tabular}


Table 2. The Main Recent Applications of PCR-RFLP and PCR-SSCP in Humans, Domestic Animals, Birds, Fishes, and Microorganisms

\begin{tabular}{|c|c|c|}
\hline Field of Applied Genetic polymorphism & Technique & Reference \\
\hline \multicolumn{3}{|l|}{ In Human Beings } \\
\hline Detection and diagnosis of carcinogenesis & PCR-RFLP & 40 \\
\hline Diagnosis of epidemiological parasitic infection & PCR-RFLP & 41 \\
\hline $\begin{array}{l}\text { Ribosomal characterization of urinary tract } \\
\text { infection }\end{array}$ & PCR-RFLP & 42 \\
\hline $\begin{array}{l}\text { Management of Helicobacter pylori caused gastritis } \\
\text { infection }\end{array}$ & PCR-RFLP & 43 \\
\hline $\begin{array}{l}\text { Genotyping the genetic loci with pharmacogenetic } \\
\text { effects }\end{array}$ & PCR-RFLP & 44 \\
\hline $\begin{array}{l}\text { Detection of genetic polymorphism in } \\
\text { atherosclerosis }\end{array}$ & PCR-RFLP & 45 \\
\hline $\begin{array}{l}\text { Genotyping Giardia lamblia infection in fecal } \\
\text { samples }\end{array}$ & PCR-RFLP & 46 \\
\hline Mitochondrial genetic diversity in infertile men & PCR-SSCP & 47 \\
\hline ABO blood group genotyping & PCR-SSCP & 48 \\
\hline \multicolumn{3}{|l|}{ In Domestic Animals } \\
\hline Wool fiber characterization & PCR-SSCP & 49 \\
\hline Milk synthesis & PCR-SSCP & 50 \\
\hline Body mass and carcass traits & PCR-SSCP & 51 \\
\hline Meat quality and fatty acid composition & PCR-SSCP & 52 \\
\hline Reproductive performance & PCR-SSCP & 53 \\
\hline Serum parameters & PCR-SSCP & 54 \\
\hline Identification of meat contamination & PCR-RFLP & 55 \\
\hline \multicolumn{3}{|l|}{ In Birds } \\
\hline $\begin{array}{l}\text { Detection the possibility of adulteration in chicken } \\
\text { meat }\end{array}$ & PCR-RFLP & 56 \\
\hline Growth and performance traits & PCR-RFLP & 57 \\
\hline Egg-production related traits & PCR-SSCP & 58 \\
\hline Body weight characteristics & PCR-SSCP & 59 \\
\hline Intra-muscular fat content & PCR-SSCP & 60 \\
\hline $\begin{array}{l}\text { Physiological variations of coding SNPs in } \\
\text { immigrated birds }\end{array}$ & PCR-SSCP & 61 \\
\hline \multicolumn{3}{|l|}{ In Plants } \\
\hline $\begin{array}{l}\text { RNA splicing polymorphism in several varieties } \\
\text { of barely }\end{array}$ & PCR-SSCP & 62 \\
\hline Fingerprinting of sequence variability & PCR-SSCP & 63 \\
\hline $\begin{array}{l}\text { Development of diagnostic markers for rapid } \\
\text { identification }\end{array}$ & PCR-RFLP & 64 \\
\hline \multicolumn{3}{|l|}{ In Fishes } \\
\hline Identification of some flatfish species & PCR-RFLP & 65 \\
\hline $\begin{array}{l}\text { Species identification by detecting environmental } \\
\text { DNA }\end{array}$ & PCR-RFLP & 66 \\
\hline \multicolumn{3}{|l|}{ In Amphibians } \\
\hline $\begin{array}{l}\text { Monitoring of species by detecting environmental } \\
\text { DNA }\end{array}$ & PCR-RFLP & 67 \\
\hline Accurate identification of overlapped species & PCR-RFLP & 68 \\
\hline \multicolumn{3}{|l|}{ In Microbial Organisms } \\
\hline Identification and differentiation of parasite species & PCR-SSCP & 69 \\
\hline Rapid identification of red algae & PCR-RFLP & 70 \\
\hline $\begin{array}{l}\text { Discrimination between closely related bacterial } \\
\text { species }\end{array}$ & PCR-RFLP & 71 \\
\hline $\begin{array}{l}\text { Identification and discrimination of mycological } \\
\text { species }\end{array}$ & PCR-RFLP & 72 \\
\hline
\end{tabular}

PCR-SSCP was recently associated with state-of-art in silico tools to assess the possible role of genetic polymorphism in African ostriches that immigrated to non-home regions. ${ }^{61}$
However, both techniques have been employed to study several mechanisms in plants with a variety of genetic polymorphism purposes that ranged from splicing alterations to fingerprinting and diagnostic markers. ${ }^{62-64}$ With respect to fish and amphibians, species identification and the detection of environmental samples and closely related organisms were recently conducted using PCR-RFLP. ${ }^{56-68}$ The PCR-SSCP was used in the detection of parasite species. ${ }^{69}$ The ease of the use of PCR-RFLP was demonstrated in its successful implementation in species identification and discrimination in algae, bacteria, and fungi. ${ }^{70-72}$

\section{Future Perspectives}

The future uses of PCR-RFLP and PCR-SSCP techniques are now being challenged because of the massive development of high-throughput DNA sequencing protocols. ${ }^{25}$ Nevertheless, such highly efficient protocols are not available in mediocratic laboratories because of budget limitations. Both techniques are highly valuable in genotyping, including wide applications in agricultural, ${ }^{73}$ medical, ${ }^{74}$ and microbiological ${ }^{75}$ genotyping research.

\section{Conclusions}

The concept of PCR-RFLP is based on the presence or absence of a particular recognition site in the target sequence, which usually does not exceed eight nucleotides in length. The concept of PCR-SSCP is based on the presence or absence of a particular mutation between normal and mutant amplicons as a result of the differences between their physical characteristics, which could be extended to include nucleotide sequences that exceed those detected by PCRRFLP. Moreover, each technique has advantages that the other technique does not provide. The PCR-SSCP method has been characterized by its ability to detect unknown mutations, but more laboratory skills are required to optimize it before it can exhibit this feature. In contrast to PCR-SSCP, PCRRFLP is easy to use and has highly specific characteristics, but it does not have the ability to detect unknown mutations in the amplified locus. Therefore, it can be stated that when the main purpose of a particular genotyping experiment is the detection of an unknown SNP, the best technique is PCRSSCP. However, when a specified locus is targeted, and there is no need to determine the neighboring sequences, PCR-RFLP is the best technique. Despite the simplicity of PCR-RFLP, it does not have the ability to identify unknown mutations. In contrast, the complexity of PCR-SSCP is usually accompanied by the ability of this technique to identify unknown mutations. Therefore, there is an urgent need for a robust, efficient, and affordable technique that combines the simplicity of PCRRFLP and the high sensitivity of PCR-SSCP.

\section{Authors' Contributions}

$\mathrm{HOH}$ Conceived the main idea and participated in solving several conceptual issues. MBSA designed the main portions of the review. Both authors shared the same efforts in this work. Both authors read and approved the final manuscript.

Conflict of Interest Disclosures

The authors declare they have no conflicts of interest. 


\section{Reference}

1. Gulija TK, Ivancic-Jelecki J, Santak M, Forcic D. Comparative analysis of CE-SSCP to standard RFLP-CE-FLA method in quantification of known viral variants within an RNA virus quasispecies. Electrophoresis. 2011;32(14):1852-1859. doi:10.1002/elps.201100010.

2. Tabone T, Sallmann G, Chiotis M, Law M, Cotton R. Chemical cleavage of mismatch (CCM) to locate base mismatches in heteroduplex DNA. Nat Protoc. 2006;1(5):2297-2304. doi:10.1038/nprot.2006.352.

3. Mahdieh N, Rabbani B. An overview of mutation detection methods in genetic disorders. Iran J Pediatr. 2013;23(4):375-388.

4. Al-Shuhaib MBS, Al-Lamy SMA, Al-Tayy HMA, Al-Thuwaini TM, Radhi AH. Single Nucleotide Polymorphism (SNP) of leptin gene in holstein cattle. Thai J Vet Med. 2018;48(2):187-201.

5. Bai L, Zhou H, Gong H, et al. Variation in the ovine KAP8-1 gene affects wool fibre uniformity in Chinese Tan sheep. Small Rumin Res. 2019;178(4):18-21. doi:10.1016/j.smallrumres.2019.07.008.

6. Vielmo A, Pena HFJ, Panziera W, et al. Outbreak of toxoplasmosis in a flock of domestic chickens (Gallus gallus domesticus) and guinea fowl (Numida meleagris). Parasitol Res. 2019;118(3):991997. doi:10.1007/s00436-019-06233-w.

7. Rennert H, Eng K, Zhang T, et al. Development and validation of a whole-exome sequencing test for simultaneous detection of point mutations, indels and copy-number alterations for precision cancer care. NPJ Genom Med. 2016;1. doi:10.1038/npjgenmed.2016.19.

8. Zhao $\mathrm{M}$, Zhou $\mathrm{H}$, Hickford JGH, et al. Variation in the caprine keratin-associated protein 15-1 (KAP15-1) gene affects cashmere fibre diameter. Arch Anim Breed. 2019;62(1):125-133. doi:10.5194/aab-62-125-2019.

9. Hidalgo A, Melo A, Romero F, et al. A PCR-RFLP assay for discrimination of Echinococcus granulosus sensu stricto and Taenia spp. in dogs stool. Exp Parasitol. 2019;200:42-47. doi:10.1016/j. exppara.2019.03.015.

10. Bandyopadhyay S, Bera AK, Sikdar S, et al. Intra-species sequence variability in 28s rRNA gene of Oesophagostomum venulosum isolated from goats of West Bengal, India. Asian Pac J Trop Med. 2010;3(7):515-518. doi:10.1016/S1995-7645(10)60124-1.

11. Sivaraman B, Jeyasekaran G, Jeya Shakila R, et al. PCR-RFLP for authentication of different species of processed snappers using mitochondrial D-loop region by single enzyme. Food Control. 2018;90:58-65. doi:10.1016/j.foodcont.2018.02.028.

12. Kim JY, Kim DK. Determination of Repeat Numbers of (CA)n in Mitochondrial D-loop using Polymerase Chain Reaction-single Strand Conformational Polymorphism (PCR-SSCP). Korean J Phys Anthropol. 2018;31(3):77-82. doi:10.11637/kjpa.2018.31.3.77.

13. Csikos A, Hodzic A, Pasic-Jahus E, et al. Applicability and sensitivity of PCR-SSCP method for milk species identification in cheese. Acta Aliment. 2016;45(1):69-76. doi:10.1556/066.2016.45.1.9.

14. Rohit A, Maiti B, Shenoy S, Karunasagar I. Polymerase chain reaction-restriction fragment length polymorphism (PCRRFLP) for rapid diagnosis of neonatal sepsis. Indian J Med Res. 2016;143(1):72-78. doi:10.4103/0971-5916.178613.

15. Rajatileka S, Luyt K, Williams M, et al. Detection of three closely located single nucleotide polymorphisms in the EAAT2 promoter: comparison of single-strand conformational polymorphism (SSCP), pyrosequencing and Sanger sequencing. BMC Genet. 2014;15:80. doi:10.1186/1471-2156-15-80.

16. Pouryasin $M$, Sharafi $H$, Behnava B, Alavian SM, Keshvari $M$, Pouryasin A. A simple PCR-RFLP method for genotyping of IFNL4 rs368234815 polymorphism in patients with chronic hepatitis C. Lab Med. 2017:48(1):51-56. doi:10.1093/labmed//mw060.

17. Rasmussen HB. Restriction fragment length polymorphism analysis of PCR-amplified fragments (PCR-RFLP) and gel electrophoresisvaluable tool for genotyping and genetic fingerprinting. InTech; 2011. doi: $10.5772 / 37724$

18. Botstein D, White RL, Skolnick M, Davis RW. Construction of a genetic linkage map in man using restriction fragment length polymorphisms. Am J Hum Genet. 1980;32(3):314-331.

19. Panneerchelvam S, Norazmi MN. Forensic DNA profiling and database. Malays J Med Sci. 2003;10(2):20-26.

20. Orita M, Iwahana H, Kanazawa H, Hayashi K, Sekiya T. Detection of polymorphisms of human DNA by gel electrophoresis as singlestrand conformation polymorphisms. Proc Natl Acad Sci U S A. 1989;86(8):2766-2770. doi:10.1073/pnas.86.8.2766.

21. Gasser RB, Hu M, Chilton NB, et al. Single-strand conformation polymorphism (SSCP) for the analysis of genetic variation. Nat Protoc. 2006;1(6):3121-3128. doi:10.1038/nprot.2006.485.

22. Shirasawa K, Hirakawa H, Isobe S. Analytical workflow of double-digest restriction site-associated DNA sequencing based on empirical and in silico optimization in tomato. DNA Res. 2016;23(2):145-153. doi:10.1093/dnares/dsw004.

23. Sunnucks P, Wilson AC, Beheregaray LB, Zenger K, French J, Taylor AC. SSCP is not so difficult: the application and utility of single-stranded conformation polymorphism in evolutionary biology and molecular ecology. Mol Ecol. 2000;9(11):1699-1710. doi:10.1046/j.1365-294x.2000.01084.x.

24. Kakavas VK, Plageras P, Vlachos TA, Papaioannou A, Noulas VA. PCR-SSCP: a method for the molecular analysis of genetic diseases. Mol Biotechnol. 2008;38(2):155-163. doi:10.1007/ s12033-007-9006-7.

25. Tebbe CC, Dohrmann AB, Hemkemeyer M, Näther A. Microbial Community Profiling: SSCP and T-RFLP Techniques. In: McGenity T, Timmis K, Nogales B, eds. Hydrocarbon and Lipid Microbiology Protocols: Microbial Quantitation, Community Profiling and Array Approaches. Berlin, Heidelberg: Springer; 2017:101-126. doi:10.1007/978-3-662-52778-8.

26. Tabit FT. Advantages and limitations of potential methods for the analysis of bacteria in milk: a review. J Food Sci Technol. 2016;53(1):42-49. doi:10.1007/s13197-015-1993-y.

27. Abula R, Zhang HL, Chen Y, Yao XK. Novel polymorphisms detected in the prolactin receptor gene of Yili horse (Equus caballus) by PCR-SSCP. J Anim Feed Sci. 2013;22(1):70-76. doi:10.22358/ jafs/66021/2013.

28. Zhu $\mathrm{X}$, Niu N, Liu $\mathrm{Y}$, et al. Improvement of the sensitivity and resolution of PCR-SSCP analysis with optimized primer concentrations in PCR products. J Genet. 2006;85(3):233-235. doi:10.1007/BF02935339.

29. Sambrook J. Molecular Cloning: A Laboratory Manual. Cold Spring Harbor, N.Y: Cold Spring Harbor Laboratory Press; 2001.

30. Bassam BJ, Gresshoff PM. Silver staining DNA in polyacrylamide gels. Nat Protoc. 2007;2(11):2649-2654. doi:10.1038/ nprot.2007.330.

31. Byun SO, Fang Q, Zhou H, Hickford JG. An effective method for silver-staining DNA in large numbers of polyacrylamide gels. Anal Biochem. 2009;385(1):174-175. doi:10.1016/j.ab.2008.10.024.

32. Fitarelli-Kiehl M, Macedo GS, Schlatter RP, et al. Comparison of multiple genotyping methods for the identification of the cancer predisposing founder mutation p.R337H in TP53. Genet Mol Biol. 2016;39(2):203-209. doi:10.1590/1678-4685-gmb-2014-0351.

33. Liu X, Zheng D, Zhou Y, Mao W, Ma J. Restriction endonucleases digesting DNA in PCR buffer. J For Res. 2005;16(1):58-60. doi:10.1007/bf02856857.

34. Kamps-Hughes N, Quimby A, Zhu Z, Johnson EA. Massively parallel characterization of restriction endonucleases. Nucleic Acids Res. 2013;41(11):e119. doi:10.1093/nar/gkt257.

35. Elavarashi E, Kindo AJ, Kalyani J. Optimization of PCR-RFLP directly from the skin and nails in cases of dermatophytosis, targeting the ITS and the $18 \mathrm{~S}$ ribosomal DNA regions. J Clin Diagn Res. 2013;7(4):646-651. doi:10.7860/jcdr/2013/5363.2873.

36. An XP, Song SG, Hou JX, et al. Polymorphism identification in goat DGAT2 gene and association analysis with milk yield and fat percentage. Small Rumin Res. 2011;100(2-3):107-112. doi:10.1016/j.smallrumres.2011.05.017.

37. Aali M, Moradi-Shahrbabak H, Moradi-Shahrbabak M, Sadeghi M, Yousefi AR. Association of the calpastatin genotypes, haplotypes, 
and SNPs with meat quality and fatty acid composition in two Iranian fat- and thin-tailed sheep breeds. Small Rumin Res. 2017;149:40-51. doi:10.1016/j.smallrumres.2016.12.026.

38. Hoy MA. Insect Population Ecology and Molecular Genetics. Chapter 13. In: Insect Molecular Genetics. 4th ed. Academic Press; 2019:515-561. doi:10.1016/b978-0-12-815230-0.00013-3.

39. Highsmith WE. Electrophoretic methods for mutation detection and DNA sequencing. In: Coleman WB, Tsongalis GJ, eds. Molecular diagnostics. New York, USA: Humana Press; 2006:85109. doi:10.1385/1-59259-928-1:085.

40. Zhang HP, Zou J, Yin Y, et al. High-resolution Melting PCR Analysis for Genotyping Lys109Arg and Gln223Arg in Patients with Renal Cell Carcinoma. Ann Clin Lab Sci. 2016;46(4):367-373.

41. Kato H, Gomez EA, Seki C, et al. PCR-RFLP analyses of Leishmania species causing cutaneous and mucocutaneous leishmaniasis revealed distribution of genetically complex strains with hybrid and mito-nuclear discordance in Ecuador. PLoS Negl Trop Dis. 2019;13(5):e0007403. doi:10.1371/journal.pntd.0007403.

42. Mahmudunnabi G, Majlish ANK, Momtaz F, Foysal MJ, Rahman MM, Islam K. Molecular detection and PCR-RFLP analysis using Pst1 and Alu1 of multidrug resistant Klebsiella pneumoniae causing urinary tract infection in women in the eastern part of Bangladesh. J Genet Eng Biotechnol. 2018;16(1):77-82. doi:10.1016/j.jgeb.2017.12.004.

43. Klesiewicz K, Nowak P, Karczewska E, et al. PCR-RFLP detection of point mutations A2143G and A2142G in 23S rRNA gene conferring resistance to clarithromycin in Helicobacter pylori strains. Acta Biochim Pol. 2014;61(2):311-315.

44. Soko ND, Masimirembwa C, Dandara C. A cost effective RFLP method to genotype Solute carrier organic anion 1B1 (SLCO1B1) c.1929A>C (p.Leu643Phe, rs34671512); a variant with potential effect on rosuvastatin pharmacokinetics. BMC Res Notes. 2018;11(1):384. doi:10.1186/s13104-018-3469-4.

45. Costa IR, Santos TR, Bento IA, et al. RFLP-PCR is more efficient than ARMS-PCR for identifying CYP2C19*2 polymorphism in atherosclerotic patients. Genet Mol Res. 2019;18(3):1-5. doi:10.4238/gmr18268.

46. Hawash Y, Ghonaim MM, Al-Shehri SS. An improved PCR-RFLP assay for detection and genotyping of asymptomatic Giardia lamblia infection in a resource-poor setting. Korean J Parasitol. 2016;54(1):1-8. doi:10.3347/kjp.2016.54.1.1.

47. Heidari MM, Khatami M, Danafar A, Dianat T, Farahmand G, Talebi AR. Mitochondrial genetic variation in Iranian infertile men with varicocele. Int J Fertil Steril. 2016;10(3):303-309. doi:10.22074/ ijfs.2016.5047.

48. Ray S, Gorakshakar AC, Vasantha K, Nadkarni A, Italia Y, Ghosh K. Molecular genotyping of $\mathrm{ABO}$ blood groups in some population groups from India. Indian J Med Res. 2014;139(1):105-111.

49. Chai W, Zhou H, Forrest RHJ, Gong H, Hodge S, Hickford JGH. Polymorphism of KRT83 and its association with selected wool traits in Merino-cross lambs. Small Rumin Res. 2017;155:6-11. doi:10.1016/j.smallrumres.2017.08.019.

50. Ibrahim AHM, Tzanidakis N, Sotiraki S, Zhou H, Hickford $\mathrm{JGH}$. Identification of the association between FABP4 gene polymorphisms and milk production traits in Sfakia sheep. Arch Anim Breed. 2019;62(2):413-422. doi:10.5194/aab-62-413-2019.

51. An Q, Zhou H, Hu J, Luo Y, Hickford JGH. Sequence and haplotypes variation of the ovine uncoupling protein-1 gene (UCP1) and their association with growth and carcass traits in New Zealand Romney lambs. Genes (Basel). 2018;9(4). doi:10.3390/ genes9040189.

52. Esteves C, Livramento KG, Paiva LV, et al. The polymorphisms of genes associated with the profile of fatty acids of sheep. Arq Bras Med Vet Zootec. 2019;71(1):303-313. doi:10.1590/1678-41629376.

53. Alex R, Ramesha KP, Singh $U$, et al. Association analysis of novel polymorphisms in 2', 5'-oligoadenylate synthetase gene with reproductive traits in indigenous and cross-bred cattle of Indian
Origin. Reprod Domest Anim. 2018;53(2):442-449. doi:10.1111/ rda.13129.

54. Salehian Dehkordi H, Zamani P. New mutations in DQA2 exon 2 and their associations with some production traits and serum parameters of sheep. Small Rumin Res. 2015;130:47-53. doi:10.1016/j.smallrumres.2015.07.022.

55. Erwanto $Y$, Abidin MZ, Sugiyono EY, Rohman A. Identification of pork contamination in meatballs of Indonesia local market using polymerase chain reaction-restriction fragment length polymorphism (PCR-RFLP) analysis. Asian-Australas J Anim Sci. 2014;27(10):1487-1492. doi:10.5713/ajas.2014.14014.

56. Djurkin Kušec I, Samac D, Margeta V, Radišić Ž, Vincek D, Kušec G. Efficiency of PCR-RFLP and species-specific PCR for the identification of meat origin in dry sausages. Czech J Food Sci. 2017;35(5):386-391. doi:10.17221/243/2016-CJFS.

57. Wang YC, Han RL, Li ZJ, et al. Polymorphisms of Flanking Region of the ASB15 Gene and Their Associations with Performance Traits in Chicken. Anim Biotechnol. 2017;28(1):53-60. doi:10.1080/104 95398.2016.1200986.

58. Zhu H, Qin N, Tyasi TL, et al. Genetic effects of the transcription factors-sal-like 1 and spalt-like transcription factor 3 on egg production-related traits in Chinese Dagu hens. J Exp Zool A Ecol Integr Physiol. 2018;329(1):23-28. doi:10.1002/jez.2156.

59. Zhao XH, Li MY, Xu SS, Liu GJ. Single nucleotide polymorphisms in IGFBP-2 gene and their associations with body weight traits on Jinghai Yellow chicken. Rev Bras Cienc Avic. 2015;17(4):497-502. doi:10.1590/1516-635X1704497-502.

60. Wang $\mathrm{Y}$, Hui $\mathrm{X}$, Wang $\mathrm{H}$, et al. Association of H-FABP gene polymorphisms with intramuscular fat content in Three-yellow chickens and Hetian-black chickens. J Anim Sci Biotechnol. 2016;7(1):9. doi:10.1186/s40104-016-0067-y.

61. Al-Shuhaib MBS, Al-Kafajy FR, Badi MA, et al. Highly deleterious variations in COX1, CYTB, SCG5, FK2, PRL and PGF genes are the potential adaptation of the immigrated African ostrich population. Comput Biol Med. 2018;100:17-26. doi:10.1016/j. compbiomed.2018.06.019.

62. Mustafa KM, Ewadh MJ, Al-Shuhaib MBS, Hasan HG. The in silico prediction of the chloroplast maturase $\mathrm{K}$ gene polymorphism in several barley varieties. Agriculture (Polnohospodárstvo). 2018;64(1):3-16. doi:10.2478/agri-2018-0001.

63. Gui Z, Liu HQ, Wang Y, et al. Detection of the genetic variation of polygalacturonase-inhibiting protein gene 2 in autotetraploid alfalfa (Medicago sativa) using an improved SSCP technique. Genet Mol Res. 2014;13(4):10184-10193. doi:10.4238/2014. December.4.13.

64. Park YJ, Nishikawa T, Matsushima K, Minami M, Nemoto K. A rapid and reliable PCR-restriction fragment length polymorphism (RFLP) marker for the identification of Amaranthus cruentus species. Breed Sci. 2014;64(4):422-426. doi:10.1270/jsbbs.64.422.

65. Caldelli A, Gigliarelli L, Bottinelli T, Palomba A, Chiesa S, Lucentini L. PCR-RFLP approaches to easily identify Pleuronectes platessa from other flatfishes: a rapid and efficient tool to control label information. CyTA J Food. 2014;12(4):331-335. doi:10.1080 /19476337.2013.876556.

66. Clusa L, Ardura A, Fernández S, Roca AA, García-Vázquez E. An extremely sensitive nested PCR-RFLP mitochondrial marker for detection and identification of salmonids in eDNA from water samples. PeerJ. 2017;5:e3045. doi:10.7717/peerj.3045.

67. Igawa T, Takahara T, Lau Q, Komaki S. An application of PCRRFLP species identification assay for environmental DNA detection. PeerJ Preprints. 2019;7:e27601v1. doi:10.7287/peerj. preprints.27601v1.

68. Igawa T, Komaki S, Takahara T, Sumida M. Development and validation of PCR-RFLP assay to identify three Japanese brown frogs of the true frog genus Rana. Curr Herpetol. 2015;34(1):8994. doi:10.5358/hsj.34.89.

69. Matini M, Rezaie S, Mohebali M, et al. Genetic identification of Trichomonas vaginalis by using the actin gene and molecular 
based methods. Iran J Parasitol. 2014;9(3):329-335

70. Kim Y, Choi SJ, Choi C. An Efficient PCR-RFLP Method for the Rapid Identification of Korean Pyropia Species. Molecules. 2017;22(12). doi:10.3390/molecules22122182.

71. Silvester R, Alexander D, Antony AC, Hatha M. GroEL PCR- RFLP - An efficient tool to discriminate closely related pathogenic Vibrio species. Microb Pathog. 2017;105:196-200. doi:10.1016/j. micpath.2017.02.029.

72. Roberto TN, Rodrigues AM, Hahn RC, de Camargo ZP. Identifying Paracoccidioides phylogenetic species by PCR-RFLP of the alphatubulin gene. Med Mycol. 2016;54(3):240-247. doi:10.1093/ $\mathrm{mmy} / \mathrm{myv} 083$

73. Al-Shuhaib MBS, Al-Thuwaini TM, Al-Fihan RA, Al-Qutbi AA.
Genotyping of Diacylglycerol Acyltransferase 2 Gene in Holstein Cattle Population. Agric Conspec Sci. 2019;84(2):211-218.

74. Mahmudunnabi G, Majlish ANK, Momtaz F, Foysal MJ, Rahman MM, Islam K. Molecular detection and PCR-RFLP analysis using Pst1 and Alu1 of multidrug resistant Klebsiella pneumoniae causing urinary tract infection in women in the eastern part of Bangladesh. J Genet Eng Biotechnol. 2018;16(1):77-82. doi:10.1016/j.jgeb.2017.12.004.

75. Nema V. The Role and Future Possibilities of Next-Generation Sequencing in Studying Microbial Diversity. In: Das S, Dash HR, eds. Microbial diversity in genomic era. Academic Press; 2019:611-630. doi:10.1016/C2017-0-01759-7. 